\title{
Canada's multiple voices diplomacy in climate change negotiations: a focus on Québec*
}

\author{
By \\ Annie Chaloux \\ Ph.D Candidate, École nationale d'administration publique \\ Research Fellow at the Canada Research Chair in International and Comparative Political Economy \\ Stéphane Paquin \\ Professor, École nationale d'administration publique \\ Chairholder, Canada Research Chair in International and Comparative Political Economy \\ Hugo Séguin \\ Lecturer, Université de Sherbrooke \\ Associate Researcher, Centre d'études internationales de Montréal
}

* This is the pre-publication draft of the article in International Negotiation, 20(2), 2015.

Given the diffuse and pervasive nature of greenhouse gas emissions, the complex task of mitigating them at the global level arguably involves much more than central governments. Like many other environmental problems, climate issues can't be constrained within national boundaries, as their scope is both international and global, while emission sources are domestic and local. Thus climate change has to be considered a multi-level and multi-stakeholder issue, one that can only be tackled successfully if all actors, at all levels of government, contribute their share using the levers and tools at their disposal.

As a consequence, managing climate change as a policy issue has proven particularly difficult in a federation like Canada, shedding new and acute light on the age-old debate surrounding Canada's ability to negotiate and implement treaties involving provincial jurisdictions (Paquin, 2013; de Mestral \& Fox-Decent, 2008). Indeed, according to Peter Stoett, "Climate change is emerging as one of the most potent and divisible political issues in Canada, reflecting [...] the difficulties inherent in developing national policy in a federal political system" (Stoett, 2009: 47).

Canada has so far failed to manage the complex governance challenges posed by climate change, both domestically and internationally. Faced with a dizzying number of competing interests and views across the country, and lacking effective coordination mechanisms among the provinces, the federal government and other stakeholders, Canada's official negotiating 
positions never represented any meaningful consensus as to what an international climate regime should look like and what Canada's contribution should be. Unsurprisingly in this context, Canada has also proven incapable of developing economy-wide comprehensive climate policies that would effectively implement the country's international climate commitments. This paper argues that this inability to face climate change from a united, pan-Canadian front, has led to the fragmentation of Canada's voice on international forums and disparate domestic GHG mitigation policies, as most Canadian provinces and the federal government today seem to pursue independent diplomacy and policy-making.

We will first review some of the theoretical underpinnings of the practice of international relations in general and in Canada in particular, arguing that one of the main contending schools of thought, multi-level governance, may be better suited to help manage complex intermestic issues such as climate change. We will then illustrate the early deadlock and paralysis in the development of a consensus-based Canadian position on climate change among the federal government and the provinces, specifically focusing on burden-sharing, namely the level of contribution Canada is willing to make to help mitigate global GHG emissions. We will finally highlight the resulting fragmentation of Canada's climate diplomacy and policy-making through the climate policies of Québec, arguably one of the most active provinces and subnational governments on this issue, but hardly the only one. This will lead to a discussion on the role and relevance of provinces as quasi-independent actors within Canada when it comes to seemingly intractable issues such as climate change.

\section{International negotiation and domestic implementation of international treaties in Canada}

For more than fifty years, international negotiations scholars have focused their attention on the impact of domestic institution over foreign policy. One of the most important contributions was made by Robert Putnam in the 1980's and 1990's. Robert Putnam $(1989,1993)$ coined the «Two-level games» metaphor to capture the dynamic and complexity of international negotiations. The Two-Level Game metaphor, and his subsequent scholarship on double-edged diplomacy, refers to the idea that the central government negotiators have to negotiate simultaneously with domestic and international actors in order to secure a negotiation. According to Putnam : "The politics of many international negotiations can be usefully be conceived as a two-level game. At the national level, domestic groups pursue their interests by pressuring the government to adopt favorable policies, and politicians seek power by construction coalitions among those groups. At the international level, national governments seek to maximize their 
own ability to satisfy domestic pressures, while minimizing the adverse consequences of foreign developments. Neither of the two games can be ignored by central decision-makers, so long as their countries remain interdependent, yet sovereign ». For Putnam, « each national political leader appears at both game boards » (Putnam, $1988: 434)$.

Since this publication, multiple comments were made on Putnam's metaphor. For example, Helen Milner and Peter Rosendorff (1997) argue that the division of power between the executive and the legislative, and elections are more important that what Putnam metaphor gives it credit for. Lisa Martin also challenges the theory of executive dominance advocated by many international negotiation theorists, including Putnam. According to Martin, the legislature in democratic regimes has the ability to block the implementation of an international obligation, even when legislative approval isn't required. The legislature may establish its influence on budgetary control, the control procedures in relation to the executive, the appointment of agents and procedures for the implementation of treaties. Thus, an international commitment negotiated without the participation of the legislature may lack credibility. International agreements gain credibility when the legislative is included in the negotiations through an institutionalized mechanism. This situation applies in both presidential and parliamentary systems. This way of negotiating reduces uncertainty. It does so, because the legislative reveals information to national negotiators, but also to other States. By participating in the negotiations, it can also reveal its societal preferences on what can be implemented. Martin demonstrates that the legislature's presence in negotiations promotes the implementation of international commitments. It, thereby, strengthens the credibility of international commitments of States, whether in the U.S. or Europe (Martin, 2000).

All of these debates are important but Putnam, Milner and Rosendorff, and Martin have not systematically study the impact of federalism, that is the division of power between the federal and the subfederal governments, on international negotiations. Nowadays, virtually all government activity affects the competence of at least one intergovernmental organization, and frequently many more. International negotiations handle themes that relate to education, public health, cultural diversity, business subsidies, the treatment accorded to investors, the removal of non-tariff barriers, barriers to agriculture, to services but also environment and climate change.

Likewise, the enlargement of the scope of international issues means that all government departments have activities that are internationalized. In this context, subfederal governments have become more aware that their political power and their sovereignty - or, in other words, their ability to formulate and implement policy - are subject to negotiation in multilateral form. Thus, since the 1960s, there has been a noticeable increase in the number of subfederal 
governments that are interested in international questions and participate actively in them. In Canada, as in Belgium, Germany, Austria, Switzerland and Spain, the role of subfederal governments over international negotiation have become more important.

Despite an increasing role of federated states and other non-central governments in international affairs, little research has been done on their role in international negotiations, with the exception of Paquin (2013) or Kukucha (2013) over trade negotiations and Chaloux and Séguin (2012) over climate change negotiation. Indeed, research has so far, dealt very little with the relationship between international negotiations and federalism and has left the topic largely unexplored despite some case studies (Paquin , 2010, 2005; Lantis 2009; Kukucha 2008, Dai 2005; Michelmann 2009).

However, there are numerous studies produced by experts on federalism. We may say that there are two markedly different schools of thought among federalism experts in the approach to the question: the centralized school and the multi-level governance school. Among the proponents of the centralized approach, one of the first theoreticians of federalism, Professor Kenneth C. Wheare, maintained that the monopoly of international relations was a "minimal" power for any federal government (Wheare, 1967: 168). In his major study, he set out the negative consequences of breaking down centralized control of foreign policy for the national interest and the operation of the international system. Robert Davis similarly affirmed that international relations issues lie at the epicenter of federal systems (Davis, 1967). Centralization of foreign affairs power is also, according to Bertrand Badie and Marie-Claude Smouts, required by international law, because a centralized political system is a necessary condition for a state to fulfill its assigned role in international law and practice (Badie \& Smouts, 1999). In essence, for the proponents of the centralized school, without the existence of a central government that has a plenary authority on its territory in relation to foreign affairs and the ability to participate in international relations and to enforce international obligations in the domestic order, inter-state relations can only be seriously compromised (Shaw, 2008). If power of co-decision is granted, this would risk paralyzing a state's foreign affairs, because every player would have a veto, resulting in harm to the state's image in the international arena (Scharpf, 1988). In Canada, many foreign affairs specialists have underlined the constitutional difficulties for the central government of negotiating and implementing international agreements when these involve provincial subjects of jurisdiction (Brown \& Fry, 1993; Harrington, 2005; Skogstad, 2012).

Thus, since 1968, according to the government of Canada, the conduct of foreign relations and international treaty making is, under international law, the sole responsibility of fully independent 
members of the international community (Government of Canada, 1968a; Paquin, 2005). Because Canadian provinces do not meet this criterion, the direction and conduct of foreign relations in federal states should be recognized as belonging to the federal government of Canada. As a result, provinces do not, according to the Canadian government, have the autonomous power to conclude treaties, to become full members of international organizations or to accredit and receive diplomatic and consular officers.

This official Canadian government doctrine of "indivisibility of foreign policy" also applies to areas of exclusive provincial jurisdiction, such as education. In those matters, the federal government should be the sole representative of Canada as a whole on the international scene (Government of Canada, 1968a, 1968b). According to this doctrine, foreign policy cannot be fragmented. It is indivisible and only the central government has the capacity to conclude legally binding treaties applicable to Canada. Further, devolution of federal authority on foreign policy is seen ultimately as the disintegration of Canada.

Legal precedents in Canada complicate this view of the federal government as the exclusive depository of international legitimacy and sole international representative for the country. Following the adoption of the Statute of Westminster 1931, the provincial government of Ontario, in the Labor Conventions Case, challenged the ability of the federal government to legislate in provincial fields of jurisdiction in order to implement international agreements (Patry, 1980:155). Indeed, after the 1930 elections, the federal Conservative government of R. B. Bennett ratified three International Labor Organization conventions: one on working hours, a second on weekly rest and a third on minimum wage. By implementing these conventions, the federal government stepped on the provinces' right to legislate in the area of labor, an exclusive provincial jurisdiction. Hearing the case brought by Ontario, the Judicial Committee of the Privy Council in London, (which was still Canada's court of final appeal until 1949), rendered its judgment in 1937. This ruling is of fundamental importance for the legal capacity of the federal government and the rights of the provinces in international relations. The judges, recalling that federalism constitutes the foundation of Canada, stated that the principle of the sovereignty of Parliament means that the provincial legislature is not obligated to pass measures that might be necessary to implement a treaty concluded by the federal executive. In this case, it is up to the provinces, where the same principle of parliamentary sovereignty applies to provincial legislatures, to amend their respective laws and regulations to give effect to the said treaty in domestic law. In 
Canada the power to implement treaties thus follows the distribution of powers, leading in some cases to an intractable paradox. As Jean-Maurice Arbour explains:

Since the legislatures are sovereign in their areas of jurisdiction, they cannot be compelled to give effect to the terms of an otherwise validly made treaty. The conclusion is thus that the provincial state, which in theory lacks any legal capacity to negotiate and conclude a treaty, has the entire authority required to implement a treaty dealing with matters reserved to provincial parliaments, and that the federal state, which possesses all the attributes of a sovereign state with respect to the conclusion of treaties, lacks some of the powers necessary to implement them throughout Canada. Perhaps nowhere more than here has Canadian federalism come up against so fundamental a problem; for it highlights the impediments both parties face in the field of international relations (1997: 160-161) [Translated from French].

In Canada, international treaties thus have to be implemented by the federal government but also by the provinces and even by municipalities. Because of that situation, Canadian provinces have become in the past 40 years more important actors in international negotiations (Kukucha, 2013, 2008; VanDuzer, 2013; Fafard \& Leblond, 2013; Paquin, 2013). Grace Skogstad even talks about a "de facto shared jurisdiction" (Skogstad, 2012:202). Two major reasons explain this situation. First, although the Canadian government can negotiate in the field of jurisdiction of the Canadian provinces, it doesn't have the power to force the provinces to implement the treaty. (Skogstad, 2012: 204; VanDuzer, 2013; Kukucha, 2013, 2009; Cyr, 2009; Paquin, 2013, 2006). International treaties have to be implemented at the proper level of government through a law of incorporation. This issue is very important since, according to de Mestral and Fox-Decent, "roughly 40 per cent of federal statutes implement international rules in whole or in part" (de Mestral \& Fox-Decent, 2008: 578). The second reason is that a fair number of international treaties now deal with both international and domestic issues and it is becoming harder than ever to determine the boundary between the two. De Mestral and Fox-Decent highlight this "frustrating" situation from the perspective of the federal government which "can commit Canada to a treaty, but [...] cannot guarantee that the treaty will be properly implemented if the subject matter falls within provincial jurisdiction. This fact can be a serious impediment to the rapid consolidation of a treaty relationship with other states" (2008: 590).

Other federal regimes are experiencing with the same kind of problems. If, in the Indian and Malaysian cases, the constitutions assign explicitly foreign relations to the federal governments, it is not the case in Australia where the courts have accorded, like in Canada, a more important role. In other countries like Austria, Germany, Switzerland and Belgium, the constitutions assign 
them explicit powers over foreign affairs. In the case of Belgium, Germany and Switzerland, they even have been assign treaty-making powers (Michelmann 2009). And no other country goes as far as Belgium where subnational governments are the sole responsible for the international projection of the internal constitutional attribution. Since the revision of the Constitution in 1993, there have been three categories of treaty in Belgium: 1) treaties that exclusively involve the powers of the federal government and which are concluded and ratified by this same federal government; 2) treaties related exclusively to community or regional powers and which are concluded and ratified by communities and regions; and finally; 3) mixed treaties (Paquin, 2010).

Proponents of the multi-level governance approach have taken stock of this Canadian paradox in international treaty negotiation and implementation and have suggested an alternative to the centralized school (Bache \& Flinders, 2004; Hocking, 1993; Hooghe \& Marks, 2003; Jeffery, 2000). According to Brian Hocking, diplomacy and foreign policy cannot be considered a monopoly of the central state (Hocking, 1993). Federated states always have an important role to play, even if only in implementing international treaties that the central state has concluded. Moreover, a central-government monopoly over international relations in a federal system risks undermining the distribution of powers between the different orders of government to the benefit of the central authorities. According to these authors, there are many examples of federal states that must operate within constitutional limitations. Other scholars from the multi-level governance school go further in arguing that "[a]s a constitutional theory, federalism affirms that both subnational and national entities constitute the sovereign state. Neither level is super- or subordinate to the other, and both are necessary to constitute the whole" (Piattoni, 2010: 207).

Many authors consider that foreign policy must now be conceived as a complex system in which the actors in a federal state structure are interlinked. They thus stress the existence of "imperatives of cooperation" between central governments and federated states. Implementation of a coherent foreign policy inevitably, they maintain, entails consulting with-and even according a significant role to-federated states through national intergovernmental mechanisms, so that they may play an active part in the country's foreign policy. Regional integration, and the rises of multilateralism and globalization have rendered the theses of the centralized approach obsolete.

In practice, despite the considerable expansion of intergovernmental relations with regard to international treaties (Hocking, 1993; Meekison, 2004), Canada still often succumbs to the 
temptation to govern from the center (Savoie, 2004). Richard Simeon goes further, contending that intergovernmental relations are the weak link in Canadian federalism (Simeon, 2004). The culture of Canadian intergovernmentalism is largely informal, intergovernmental arrangements are rarely binding, and they operate by flexible consensus.

Thus, climate change diplomacy and domestic policy-making clearly illustrate the atrophy of intergovernmental coordination within Canada, even though mitigating GHG emissions calls on numerous and diverse policies, some controlled centrally, while most are determined and implemented at provincial and local levels.

In Canada, climate change cannot be considered an exclusive federal jurisdiction. The Canadian Constitution Act of 1867 does not specify environment as either a federal or provincial jurisdiction. Therefore, environmental issues are tackled within various constitutional jurisdictions at both provincial and federal levels. For instance, provinces have primary jurisdiction over many areas related to climate change such as natural resources (including energy), municipal institutions (including urban and territorial planning), transportation (including public transit) and so on (Harrison, 1996). They also can regulate pollutants from large industrial emitters, including agricultural practices. On the other hand, federal jurisdiction over climate change is more diffuse and general, such as peace, order and good government, criminal law, navigation, taxations and residual powers, as well as shared powers with provinces concerning agriculture and commerce (Dufault, 2006; Harrison, 1996). Since both levels of government have some part of the responsibility over environmental issues, many authors contend that both levels of governance do not have any choice but to cooperate and coordinate their actions. On climate change, Macdonald and VanNijnatten call for the provinces "[to] be brought back to the table, by whatever means necessary, since the federal government does not have the jurisdictional mandate to solve the problem alone" (2005: 19).

This constitutional situation poses a sizeable problem for Canada: provincial collaboration is inevitable when the provincial fields of power are affected by a treaty or international convention. But there is no general framework for federal-provincial consultation and very little uniformity of approach (de Mestral, 2005: 319-322). While some contend that "generally, the federal government will not ratify a treaty until it is confident that Canada's domestic law [including provincial laws] is consistent with the treaty and that there are sufficient legal powers in place to comply with its obligations" (De Mestral \& Fox-Decent, 2008: 624), evidence shows that this is 
far from being systematically the case. For example, the Canadian government ratified the two NAFTA side agreements on environmental cooperation and labor-both areas involving provincial oversight-even in the context of a big disagreement with some provinces (Kukucha, 2003: 58-64). Moreover, while an issue such as climate change calls for a strong level of coordination among levels of governance, such coordination has escaped Canadian decisionmakers for the last two decades. In fact, both the UN Framework Convention on Climate Change (UNFCCC) and the Kyoto Protocol were ratified by the federal government-in 1994 and 2002 respectively-in the absence of consensus among provinces as to the implementation of their provisions.

On climate change, inclusion of provinces within an intergovernmental coordination mechanism has proven weak and poorly institutionalized, with their role declining in the last decade. While some of these mechanisms do exist, such as the Canadian Council of Ministers of the Environment (CCME), their influence remains weak over foreign policy issues. Furthermore, since 2006, provinces have been even less involved in the foreign policy process over climate change issues, despite the clearly expressed desire of some provinces to be consulted and to participate actively in the process (Chaloux \& Séguin, 2012; Vannijnatten \& Boardman, 2009).

We will now turn to the evolution of climate diplomacy and federal-provincial relations in Canada since 1992, the year of the adoption of the UN Framework Convention on Climate Change in Rio, in order to understand the dynamic of climate-related intergovernmental relations in Canada.

\section{Canadian climate change foreign policy and policy making (1992-2012)}

Canada's foreign policy on climate change, as developed and implemented by the federal government, has evolved considerably since the late 1980s. Although Canada was seen as one of the global leaders pushing for strong international environmental regimes in the lead-up to the Rio Earth Summit of 1992, most notably on climate change, it progressively experienced huge difficulties developing domestic policies in accordance with its international commitments from the end of the 1990s through the 2000s. Canada's incapacity to implement some of the main elements of the developing climate regime turned it from a leader to a more and more reluctant participant, ultimately leading to its defection from the Kyoto Protocol at the end of 2011. 


\section{Evolution of Canadian climate policy (1992-2012)}

The late 1980s and early 1990s can be considered the apex of Canada's international environmental leadership. In 1988 in Toronto, alongside the World Meteorological Organization (WMO) and the United Nations Environment Program (UNEP), the Canadian government was host to one of the very first high-level conferences on climate change. During his opening speech, Prime Minister Brian Mulroney reaffirmed the importance of an international law of the atmosphere citing in example Canada's proactivity on acid rain and ozone depletion (May, 2007), revealing the importance and level of concern of this emerging international issue for the federal government.

Subsequently, the federal government pledged to stabilize Canada's greenhouse gas emissions by 2000 to 1990 levels, two years before the adoption of such a goal during the negotiations leading to the United Nations Framework Convention on Climate Change (UNFCCC) (Windfield \& Macdonald, 2008). Canada was also to be among the first countries to ratify the Framework Convention in December 1992.

In the following years, Canada's climate leadership diminished, the result of internal divisions as well as of the influence of the U.S. economy on the country's international and domestic policies. The federal nature of Canada highlighted major intergovernmental tensions, exacerbated by overlapping jurisdictions, leading to major conflicts in the establishment of a common Canadian GHG emissions reduction target. The consensual nature of the intergovernmental process further weakened the capacity of the new Chrétien government to hammer out an agreement. In addition, the considerable interweaving of the Canadian economy with that of the United States also increased tensions within Canada, where the federal government hesitated between macroeconomic integration of climate-related policies and a more independent policy on global warming (Simpson, Jaccard \& Rivers, 2008; VanNijnatten, 2009).

In the months prior to the Third Conference of the Parties of the UNFCCC (COP-3) in Kyoto and despite these tensions, provincial and federal environment ministers finally agreed on a Canadian position on the global burden sharing of necessary GHG emission reductions. Canada's contribution at Kyoto was a commitment to stabilize its emissions to 1990 levels by 2008-2012, a target Québec refused to endorse (SCIC, 1997b). The province wanted to adopt far more ambitious reduction targets than the ones agreed to by the other provinces. Despite this 
quasi consensus reached with most of the provinces, the federal government finally decided to endorse a more ambitious GHG emissions reduction target of three percent below 1990 levels (Simpson, Jaccard \& Rivers, 2008; Windfield \& Macdonald, 2008). At Kyoto, in the heat of the negotiations and influenced by much higher U.S. and European commitments, it then increased Canada's commitment even more, to a six percent reduction of domestic emissions below 1990 levels. The final target for Canada as a whole was thus well beyond the one originally approved by a vast majority of provinces. This event generated deep tensions between the federal government and some provinces on this issue (Bakvis, Baier \& Brown, 2009; Simpson, Jaccard \& Rivers, 2008; VanNijnatten, 2009).

Moreover, in the months prior to Canada's ratification of the Kyoto Protocol, the rejection of the Protocol by the new U.S. administration of George W. Bush put additional pressure on Canada's willingness to regulate GHG emissions. Despite this, and after certain concessions were made by the European Union-on carbon sinks in particular-Canada finally agreed to ratify the Kyoto Protocol (Bakvis, Baier \& Brown, 2009; Simpson, Jaccard \& Rivers, 2008).

From 1997 on, it took eight years before the Kyoto Protocol came into force, in February 2005. During that period, GHG emissions continued to grow throughout the country and the development of domestic public policies to mitigate GHG emissions at the federal level proved difficult to achieve. A first climate action plan was submitted in 2002, to be immediately rejected by several provinces. A new national climate change action plan was then introduced in April 2005, with the objective to reduce Canada's emissions by 270 megatons per year. Unsurprisingly, this plan remained vague on the means to achieve this end, proposing the establishment of a carbon market for large industrial emitters, calling on some voluntary measures and relying on buying international emissions credits to fulfill parts of its goal (Harrison, 2007). In sum, although Canada did ratify the Protocol in December 2002, it never provided substantive leadership on the issue of its implementation. According to some advisers and high officials, Canadian authorities knew it would be extremely difficult to meet the country's self-imposed emissions reduction targets for the first commitment period of 2008-2012 (Goldenberg, 2006; Simpson, Jaccard \& Rivers, 2008: 71).

The arrival in Ottawa of a new Conservative government in January 2006 definitively transformed Canada's foreign policy, notably on climate change (Harrison, 2007; Macdonald, 2009). The ideological position of the Conservative Party and its new Prime Minister, who 
previously referred to the Kyoto Protocol as a "socialist scheme," has clearly set the tone for the way the new government will handle this environmental issue in the years to come (CBC, 2007). As well, political convergence between the new government of Canada and the U.S. administration of George W. Bush substantially modified Canada's positions with regards to climate, as many federal programs related to climate change were cancelled and federal expenditures related to climate change were cut by almost 40\% (Bramley \& Demerse, 2006). As well, a new "made-in-Canada" action plan, produced by the Conservative government in 2007, was much less ambitious than the previous one, the federal government officially rejecting the GHG emissions reduction target set for the country by the former Liberal government and replacing it by a much less stringent one, pegged on the one adopted by the U.S. Administration, and modifying the baseline-year of reference (from 1990 to 2006) to allow increased levels of domestic emissions and cutting funding for climate policies (Harrison, 2007; Macdonald \& VanNijnatten, 2010).

Changes were also to be made to Canada's foreign climate policy. In 2006, at COP12 (Nairobi) federal government representatives, including Conservative environment minister Rona Ambrose, adopted a hardline ideological discourse on climate change, close to the one adopted by the U.S. Republican administration (Macdonald \& VanNijnatten, 2010). Many analysts also hinted at Canada increasingly acting in obstruction to the UN negotiations process (Ott, Sterk \& Watanabe, 2008; Smith, 2008) and undermining some of the international climate regime's principles and language. Indeed, the federal government veered away from some of the key pillars of the UNFCCC regime, such as the principle of common, but differentiated responsibilities and respective capacities, Canada (with other allies such as the U.S.) trying to shift the burden of emissions reduction away from developed nations to emerging economies, a move that was seen as a rejection of the internationalist and consensus-seeking approach that had shaped Canadian climate policy for the last 20 years. The recent withdrawal of Canada from the Kyoto Protocol in December 2011 has to be seen as the culmination of this new foreign policy posture. In sum, according to Boardman:

Support to environmental multilateralism has been steadily eroded by factors unrelated to the environment, such as a general disenchantment with UN-style cooperation, the Harper government's preference for consolidating Canada-US ties, the appeal of classical-liberal ideas of the small state and trade liberalization, and competition for priority from energy supply issues and traditional notions of security (Boardman, 2009: 138). 
As such, Canada's influence has decreased over the years, as many country delegates and international governmental and nongovernmental organizations have increasingly viewed Canada as a spoilsport on climate change. Since 2006, Canada has cumulated many "Fossil of the Day" awards-a prize given each year by more than 400 environmental non-governmental organizations (ENGOs) worldwide-at the UN-led climate negotiations (Climate Action Network International, 2011), in addition to a flood of criticisms from many delegates at the Conferences of the Parties, from both developing and developed countries (Cardinal, 2007a, 2007b; Robitaille, 2006). Similarly, the United Nations Development Program (UNDP) also denounced Canada's climate position in its 2007-2008 annual report (UNDP, 2007: 118). The leader of the Intergovernmental Panel on Climate Change (IPCC), Rajendra Pachauri, went even further, saying, "[t]his particular government has been a government of skeptics. They do not want to do anything on climate change" (AFP, 2007).

\section{Federal-provincial intergovernmental process}

While Canada's foreign policy on climate has changed over time, so have federal-provincial consultative processes and mechanisms which have evolved in different waves, more or less deliberate and inclusive, depending on the government in place.

Following the Toronto Climate Conference in 1990, provinces began to be involved in intergovernmental processes, such as the Task Force on Energy and the Environment. They were also consulted in the lead-up to the UNFCCC in 1992 within a Provincial-Territorial Advisory Committee which was designed to keep provinces informed of the negotiations and to provide for their input; provinces could also play an advisory role to the Canadian Delegation during the Intergovernmental Negotiating Committee for the Framework Convention on Climate Change $^{1}$ (Smith, 1998). Nevertheless, although such a consultation process was in place by early 1990, both Dufault and Smith believed that it did not lead to a real "partnership" between the federal and provincial governments for the development of Canada's international climate policy (Dufault, 2006). For Smith:

\footnotetext{
1 Some provinces such as Alberta (First session, Washington D.C., 4-14 February 1991; Second session, Geneva, 19-28 June 1991) and New Brunswick (Fourth session, 9-20 December 1991) had representative advisors to the Canadian Delegation.
} 
Following UNCED [the 1992 Earth Conference in Rio] the domestic institutional structures for discussion pertaining to implementation were established. In 1992 the Canadian Ministers of Energy and Environment approved a new "Comprehensive Air Quality Management Framework for Canada." The Framework recognizes the need for cooperation between the federal, provincial and territorial governments on air issues. The right of the federal government to negotiate international agreements is protected but there is also a commitment to consult the provinces "including the opportunity where appropriate for the direct provincial/territorial representation on Canadian negotiating teams." The inclusion of the phrase "where appropriate" is significant because it protects the right of the federal government to function as the sole representative of Canada in international agreements and gives the flexibility to determine when consultation is appropriate (1998: 8).

Therefore, after Rio, the federal government institutionalized the cooperation with provinces through different committees, even setting up a Joint Ministers Meeting (which included provincial and federal Energy and Environment ministers) to develop a national position on the fast evolving negotiations over an international climate regime. While these institutionalized interfaces were maintained after the arrival of a new Liberal government in Ottawa in 1993, divergences soon appeared on the level of commitment that the country should make to mitigate global GHG emissions. Provinces such as Alberta stated that they did not want any binding emissions reduction commitments and that they much preferred voluntary approaches and policies. Other provinces, such as Ontario, British Columbia and Québec, wanted regulatory measures as well as a more ambitious commitment (Stilborn, 2003; Macdonald, 2009). A "consensus" 2 finally emerged through the pursuit of the JMM meetings in Regina in November 1997, where provinces agree to the stabilizing of the country's emissions at 1990 levels by 2010, a few weeks before the third Conference of the Parties (COP3) held in Kyoto, Japan.

As mentioned earlier, the unilateral decision by the federal government to go beyond the Regina consensus and to offer a $-3 \%$ reduction of domestic emissions as Canada's opening negotiation position in Kyoto, to be increased to $-6 \%$ at the end of the Conference, was met with consternation by many provinces (Harrison, 2007; Macdonald \& Smith, 1999; Stilborn, 2003). To ease pressure at the First Ministers' meeting following the adoption of the Kyoto Protocol, the federal government agreed to establish a process "that will examine the consequences of Kyoto and provide for full participation of the provincial and territorial governments with the federal government in any implementation and management of the Protocol" (SCIC, 1997a). While

\footnotetext{
${ }^{2}$ Except that Québec asked for a more ambitious commitment (see the Press Release of Paul Bégin, Environment Minister, Regina, November 12, 1997).
} 
some provinces seemed reassured by the promise of intergovernmental discussions and partnership for the elaboration of an equitable climate change action plan, tensions remained over how to deal with climate change at a national level, as many provinces held diametrically different views.

From then on and until 2002, provincial and federal ministers and high-level civil servants met on a regular basis to try to hammer out a consensus on a national climate change action plan. By November 2002, lack of consensus among provinces led the federal government to unilaterally submit such a plan. According to Sheila Copps, former Minister of the Environment: "[t]here was no way that Alberta would agree to any reduction in fossil-fuel emissions" (cited in Harrison, 2007: 101). Provinces were largely divided over the federal government's proposed policy package, Alberta staunchly opposing it while Manitoba and Québec ardently defended the Canadian position adopted in Kyoto while expressing reservations over the federal government's plan.

In the end, and despite intergovernmental coordination and consultation mechanisms, both Canada's official position in Kyoto and the federal government's climate action plan were imposed unilaterally by the federal government. The provinces were indeed consulted, but intractable positions led to increased tensions and deep divisions between the federal and provincial governments over the climate change issue (Stilborn, 2003). Subsequently, loss of confidence in the consultative process limited Canada's ability to implement strong measures to achieve the Kyoto Protocol, and progress in this regard remained extremely weak (Smith, 2008).

Despite a discourse promoting an open federalism based on multilateralism, the arrival of the Conservatives in 2006 did not favor the development of intergovernmental relations on the issue of climate change. In fact, according to Gauvin, the number of intergovernmental meetings dropped significantly since 2006 (Gauvin, 2012), and decisions such as the adoption of an intensity based approach, included in the Conservative government Turning the Corner climate change action plan, were rejected by several provinces (Ontario, Québec, British Columbia and Manitoba) (Bramley, 2008).

As a national consensus on implementing domestic climate policies became more and more elusive, the Conservative government changed Canada's international positioning to a more hardline position mimicking the U.S. administration. Numerous provinces disagreed with this. For 
example, in 2006, Québec sent its Minister of the Environment to Nairobi (COP-12) to present the province's dissenting voice regarding the federal government's position, which it considered unsatisfactory and not audacious enough (Québec, 2006). In the years that followed, Québec asked for an official place within the Canadian delegation, and reiterated that the Canadian position must be the result of intergovernmental cooperation instead of a unilateral position (Canadian Press, 2009). These positions irritated the Conservative government and generated frictions which culminated at COP-15 in Copenhagen, when Premier Jean Charest stated, "in a federal system of government, we [the provinces and the federal government] are equal, we are not a junior government of the federal government [...] there is a sharing of powers between us" (Canadian Press, 2009). These statements demonstrated the weaknesses of intergovernmental processes related to climate change foreign policy, and more importantly, that these debates were certainly not over.

It can be said that despite intergovernmental coordination and consultation mechanisms and processes put in place in Canada since the early 1990s, no consensus was ever reached on the most substantive issues such as the level of Canada's contribution to global emissions reductions or the policy packages that had to be put in place across the country to fulfill our international mitigation commitments. On these two core issues, Liberal and Conservative governments have always acted unilaterally, trying to impose a way forward for the country as a whole. In the end, Canada keeps on making ever weaker international commitments to mitigate GHG emissions that are not supported domestically, commitments that have next to no chance of being met for lack of domestic consensus among all levels of governance.

This quagmire led many provinces to develop their own climate policies with accompanying international dimensions and extensions. By the mid 2000s, the majority of Canadian provinces had adopted economy-wide emissions reduction targets along with relevant policy packages in areas of provincial jurisdiction. Alberta had developed its own cap-and-trade system for its energy sector, British Columbia had introduced the continent's first full-fledged carbon tax and Ontario had undergone its own energy revolution and was in the process of shutting its polluting coal plants. Four provinces, Ontario, Québec, British Columbia and Manitoba, making up 80\% of Canada's GDP, had linked with some U.S. states within the Western Climate Initiative (WCI) to create the continent's first economy-wide carbon market. In essence, many Canadian provinces had started behaving like quasi-independent actors on the margins of the international climate regime, taking on commitments, implementing policies to reach them, linking with other 
provinces, U.S. states or others to adopt regulations and develop partnerships. By the mid 2000s, there was no such thing as a Canadian voice on climate change, neither internationally, nor domestically. As an international actor, Canada had become a fragmented entity.

\section{International climate negotiations and Canadian federalism: the case of Québec}

Constant tensions on climate change within Canada have prompted most provinces to act independently or even to develop an autonomous foreign policy-a green paradiplomacy-and to distance themselves from policies driven by successive federal governments in this regard (Chaloux \& Séguin, 2012). While we could have chosen to illustrate this fragmentation using other provinces as case studies, we now briefly turn to Québec-arguably one of the provinces most active on climate change-as such an autonomous actor both within Canada and internationally. We will now explore how Québec has tried to shape the federal government's climate policies and international positioning, while also trying to shape developing rules and norms within the evolving international and regional climate regime.

\section{Québec, the international climate change negotiations and paradiplomatic strategies}

One can trace the roots of Québec's climate diplomacy—or paradiplomacy, as some prefer to call diplomatic relations of non-sovereign states-to the Gérin-Lajoie Doctrine in the 1960s. Simply put, this doctrine, first enunciated formally in 1965, states that Québec has jurisdiction abroad in its areas of exclusive jurisdiction (Paquin, 2006: 31-34). As climate change issues bestow many jurisdictional powers on provinces, Québec's interest in climate change developed quite early and from the onset took both an international and a domestic perspective. As far back as 1992, the province sent observers to the United Nations Conference on Environment and Development in Rio de Janeiro (Québec, 1995), which gave birth to major international environmental treaties such as the UN Framework Convention on Climate Change (UNFCCC) and the Convention on Biological Diversity (CBD).

This interest continues to this day, Québec developing various strategies in order to ensure its presence in these international negotiations, not only within the Canadian delegation, but also going beyond the Canadian vector to develop its own paradiplomatic strategies towards climate change internationally and regionally. 
As the official UN negotiations cannot allow non-sovereign States to participate directly in the negotiation process (Conferences of the Parties (COP), Meetings of the Parties (MOP)), Québec's participation in international climate negotiations took a different route. In fact, several mechanisms allow its representatives to take part indirectly in the process, and thus to assert its interests and to create or deepen existing partnerships. Historically, the government of Québec has used some intra-channels, such as the option to delegate representatives to the Canadian diplomatic delegation. Through the Canadian delegation, Québec representatives have access to the negotiating forums, the press conference rooms and side events. This kind of representation allows Québec delegates, it is the case also of other Canadian provinces that sends delegates, to intervene directly with Canadian diplomats and try to influence some of the positions they take on behalf of Canada ${ }^{3}$.

If we look more closely at Québec green paradiplomacy since 1995 (corresponding to the first Conference of the Parties in Berlin), we note the importance attributed to the international climate negotiations by the government of Québec. Regardless of which federal party forms the government, there is a systematic presence of Québec's civil servants at these Conferences $\left(19 / 19^{4}\right)$. Ministers (12/19) attended a majority of these conferences, and the Premier of Québec chaired the Québec delegation at two recent conferences (2/19). These representatives were included, with some exceptions, in the Canadian diplomatic delegation.

However, Québec's presence goes far beyond its mere participation in the Canadian delegation. Indeed, during the Conferences of the Parties, Québec participated as well in some forums/side events held in parallel to the negotiations, and organized bilateral or multilateral meetings at all levels, to develop or deepen partnerships, and to promote its major goal - the recognition of the role of non-sovereign states in the regulation of global climate change. In fact, since 2005, the Québec government has also been actively involved in the activities and initiatives undertaken

${ }^{3}$ Quebec is not the only subnational actors to be active in Climate change negotiation many other Canadian provinces but also US states, like California, are also working to influence the negotiation. In Australia, the states have been active in promoting the emissions trading system due to the Commonwealth's previous refusal to ratify the Kyoto Protocol. Some Australian States like, Victoria, New South Wales and also South Australia supported the 2005 Federated States and Regional Governments on Climate Change with Bavaria, Scotland, Catalonia, Sao Paolo but also California and Quebec (Twomey, 2009 :55). Many other subnational government are part of many international organizations, which aim to promote the role of non-sovereign states in the fight against global warming: the Climate Group and the Network of Regional Governments for Sustainable Development (nrg4SD).

${ }^{4}$ These data correspond to the number of times each actor attended on the total COPs. 
by two international organizations which aim to promote the role of non-sovereign states in the fight against global warming: the Climate Group and the Network of Regional Governments for Sustainable Development (nrg4SD). The Climate Group represents both federated / subnational governments and large multinational businesses promoting the development of green technologies and a "clean revolution" (Climate Group, 2013). Québec became a member in 2007, joining many other federated states, regions and businesses sharing compatible and complementary goals. Today, more than 24 federated states or regions, and nearly 40 companies are active within the Climate Group (Climate Group, 2013). Québec has remained an active member of this organization, regularly co-chairing (in 2005, 2009 and 2010) the "Climate Leaders Summit," one of the highlights of the organization, an event taking place on the margins the Conferences of Parties of the UNFCCC. Québec also recently joined the Network of Regional Governments for Sustainable Development (nrg4SD). This international organization represents subnational and federated states at the UN level on issues related to sustainable development. Established in 2002 at the World Summit of Johannesburg for sustainable development (Rio +10), nrg4SD also seeks to encourage the participation of non-sovereign states in international environmental issues, including climate change and the protection of biodiversity. During COP-16 in Cancun, nrg4SD, also with the Climate Group, made representations for the recognition of subnational governments in negotiating texts (NRG4SD and Climate Group, Proposals to add references to the subnational level of governance in the AWG-LCA negotiating text of 2010 (FCCC/AWGLCA/2010/14), September 2010).

Moreover, other representations are made at every COP by Québec's delegation: bilateral meeting with representatives of sovereign and non-sovereign states, meetings with businesses, organizations and members of civil society and so on. Thus, Québec's participation in the Conferences of the Parties is undertaken in order to underscore the increasing importance of the meso level in the regulation of this global common resource problem, and that it is through a multi-level governance perspective that the solutions to the issue of climate change will be found and implemented, through a transnational climate governance perspective (Andonova, Betsill \& Bulkeley, 2009).

This perspective of transnational and multi-level governance promoted by Québec and other subnational entities is not solely limited to the UN negotiations process. In fact, Québec has been involved in several subnational multilateral organizations in North America, redefining cross-border relations along the $49^{\text {th }}$ parallel on the climate issue. Through the Conference of 
New England Governors and Eastern Canadian Premiers where Québec is an active member, a regional climate change action plan was adopted in 2001. The U.S. States and Canadian provinces agreed on common measures, on a regional GHG emissions reduction goal aimed at stabilizing greenhouse gases at 1990 level for the year 2010, on reducing GHG emissions by $10 \%$ by 2020 , and, ultimately, on reducing these emissions to levels that do not cause a threat to the global climate system (between 75 to 85\% below 2001 levels by 2050) (NAG-ECP, 2001). As well, Québec, jointly with California, implemented the first cross-border carbon market in North America, covering a large spectrum of action. According to the organization, in 2015, when the program will be fully implemented in each state, it will cover nearly $90 \%$ of GHG emissions ( $\mathrm{WCl}, 2010)$.

\section{International climate negotiations and Québec's other strategy: The implementation process}

Finally, in addition to investing in various international and regional forums to defend and promote its interests, Québec has also chosen to implement domestically most provisions of the international climate regime. In doing so, Québec chose to broaden the scope of the GérinLajoie Doctrine and argued that it was also responsible for the implementation of the Kyoto Protocol in its own areas of jurisdiction (Chaloux \& Séguin, 2012). By systematically claiming its responsibility, the province in effect tried to legitimize itself as a full-fledged, autonomous actor on climate change, both internationally and domestically.

In April 2001, Québec's National Assembly adopted a unanimous parliamentary motion of support for the Kyoto Protocol, and expressed its willingness "to do its fair share" in the context of a "greenhouse gas emissions reduction strategy in Canada," considering Québec's constitutional jurisdictions (Québec, 2001). Then, in 2006, the Québec government went a step further, by the adoption of the 2006-2012 Climate Change Action Plan. By doing this, the province demonstrated its clear commitment to implement the Kyoto Protocol on its territory. In addition, in December 2007, the province adopted a decree in which it declared itself bound to the Kyoto Protocol and committed to incorporate the provisions of the Protocol into domestic laws, through the implementation of its 2006-2012 Climate Change Action Plan (Québec, 2007).

The 2006-2012 action plan called for a greenhouse gas emissions reduction target of $6 \%$ below 1990 levels by 2012. It implemented a series of targeted measures to achieve this goal. The Plan also included some measures focusing on adaptation to climate change impacts. It has 
been financed by a new levy on hydrocarbons, one of the rare carbon taxes on the continent. It is important to note that with this plan, Québec (1) stopped waiting for the implementation of an elusive federal climate plan, (2) imposed a significant GHG emissions target on all economic sectors of the province (transportation, energy, agriculture, waste management, industries, etc.), and (3) mostly relied on its own financial resources to get the job done (Gouvernement du Québec, 2008; Chaloux \& Séguin, 2012).

Québec also developed additional public policies related to climate change in recent years (a 2006-2015 Energy Strategy and Public Transit Policy, among others). In the lead-up to the 2009 Copenhagen Conference, Québec adopted a new emission reduction target of $-20 \%$ below 1990 for the year 2020, the same as the European Union's own commitment for the Kyoto Protocol's Second Commitment Period (2013-2020), reflecting Québec's aspiration for strong action at the international level. This goal was confirmed by the adoption of a second climate change action plan of 2013-2020, in which Québec seeks to implement more ambitious actions, and where it sets up different instruments for achieving the implementation of a carbon market with California, in the context of the Western Climate Initiative. The current Parti Québécois government has also pledged to raise the reductions target to $-25 \%$ below 1990 levels by 2020 .

As an industrialized society, Québec seems to have implemented most of the requirements of the United Nations Framework Convention on Climate Change (UNFCCC) and the First Commitment Period of the Kyoto Protocol, independently from the Canadian federal government. Chaloux and Séguin (2012) identified three main types of commitments under the UNFCCC and the Kyoto Protocol for industrialized countries: (1) commitments to reduce emissions; (2) commitments to transparency and accountability; and (3) commitments to support developing countries. The study leads us to believe that Québec complies autonomously with these requirements, with the notable exception of meaningful support to developing countries, where Québec has yet to invest substantial resources. ${ }^{5}$

In sum, these various examples of a province's international activities show the relevance of these quasi-independent actors in the management and governance of this global environmental problem. We believe an analysis of other province's climate policies, both internationally and domestically, would have shown similar results. Furthermore, it brought to the forefront the

\footnotetext{
${ }^{5}$ One can argue that Quebecers as a whole do contribute by funding part of Canadian government support to developing countries through the federal tax system.
} 
complexity and the inadequacy of a centralized approach in a federal system to deal with a multi-level and multi-stakeholder issue such as climate change.

\section{Conclusion}

In conclusion, the work of Putnam, Milner and Rosendorff, and Martin offer a valuable perspective on the complex political process international negotiation and ratification. These approaches have been used for many years to explain the influence of domestic actors in international negotiations. The approaches of these scholars are interesting but they completely downplay the role of subfederal governments in international negotiations. As we saw, subfederal governments are becoming more important and cannot be ignored in climate change negotiations. Federalism and intergovernemental negotiations within a federal regime are a key factor in understanding climate change negotiations in a country like Canada.

In this article, we have shed light on the complexity of international climate change negotiation for a federal regime like Canada where there is no clear attribution of full power to international negotiation. We have also seen that in recent years, Canadian provinces, but especially Québec, have become intensely involved in climate change paradiplomacy. That situation has led to a Canadian paradox in that while Canada opted out of the Kyoto protocol in 2011, the Government of Québec claims it will respect the protocol and act accordingly. In this regards, Canada is not alone in this situation even though it is an extreme case.

We have also seen that the current climate negotiations process in Canada is inadequate because it does not allow provinces to intervene effectively in the negotiation and implementation process, despite several constitutional powers attributed to them. The weakness of the intergovernmental process has created tensions, and has pushed some provinces to overcome the inherent difficulties arising from the nature of Canadian federation and to develop an international leadership in the management of this global environmental problem.

Besides, the particular case of Québec's participation in global climate change governance is a fruitful example of the redefinition of federalism in this global context. The internationalization of its activities over the years is revealing in this regard, both through the UN process and with its North American partners. According to several authors, it is now inadequate to think of a unique national interest, and hence, it is fundamental to redefine the way international negotiations 
scholars see the regulation of global problems such as climate change, to include different kinds of actors in the process.

In sum, the recognition of the relevance of subnational international activity in Canada could be an opportunity for the federal government to really adopt an "open federalism" perspective, to improve its relations with its provincial counterparts, and finally, to demonstrate the good faith of Canada in the international negotiation process and in the regulation of global environmental issues. This situation also applies in other federal countries like Australia or even the United States.

\section{References}

(2011). About. Climate Action Network International, Climate Action Network International Online. <http://www.fossiloftheday.com?page_id=2\%3E.

AFP (2007). "Nobel Climate Panel Chief Raps Canada on Carbon Cuts," Agence France Presse. Online. <http://afp.google.com/article/ALeqM5hjgJAYTz1867ZFCzP0IQIDnFdDcA\%3E.

Arbour, J.-M. (1997). Droit international public, $3^{\text {rd }}$ ed. Cowansville: Éditions Yvon Blais.

Andonova, Liliana B., Michele M. Betsill and Harriet Bulkeley (2009). "Transnational Climate Governance," Global Environmental Politics, vol. 9, no 2, p.52-73.

Bache, lan, and Matthew Flinders (2004). Multi-Level Governance. Oxford: Oxford University Press: $237 \mathrm{p}$

Badie, Bertrand, and Marie-Claude Smouts (1999). Le retournement du monde: Sociologie de la scène internationale, 3rd edition, Paris: PFNSP et Dalloz.

Bakvis, Herman, Gerald Baier and Douglas M. Brown (2009). Contested Federalism: Certainty and Ambiguity in the Canadian Federation. Toronto, Oxford University Press, $304 \mathrm{p}$

Boardman, Robert (2009). "Canadian Environmental Policy in the Global Context: Obligations and Opportunities," in Debora L. Vannijnatten and Robert Boardman (eds.), Canadian Environmental Policy and Politics. Prospects for Leadership and Innovation, 3rd edition, Toronto: Oxford University Press, p. 137-149.

Bramley, Matthew (2008). "Far from Turning the Corner," Carbon Finance, June 20, 2008.

Bramley, Matthew, and Clare Demerse (2006). Climate Change, Kyoto and the New Federal Government: Concerns and Expectations. www.pembina.org. 
Brown, Douglas M., and Earl H. Fry (1993). States and Provinces in the International Economy. Berkeley: Institute of Governmental Studies Press, 248 p

Canadian Press (2009). "Copenhague: Charest avertit Harper," Les affaires.com, December 16, 2009.

Cardinal, François (2007a). "L'honnêteté du Canada mise en doute," La Presse, 12 December 2007.

Cardinal, François (2007b). "Même la Chine fait la leçon au Canada," La Presse, 11 December 2007.

CBC (2007). "Harper's Letter dismisses Kyoto as "Socialist Scheme"," CBC News, January 30, 2007. Online. <http://www.cbc.ca/news/canada/story/2007/01/30/harperkyoto.html\%3E.

Chaloux, Annie, and Hugo Séguin (2012). "États fédérés et mise en oeuvre de traités climatiques internationaux: le cas du Québec," Revue de droit de l'Université de Sherbrooke, vol. 41.

Climate Group (2013). The Climate Group. Online. <http://www.theclimategroup.org/

Cyr, Hugo (2009). Canadian Federalism and Treaty Powers. Organis Constituionalism at Work, New York: P.I.E. Peter Lang.

Davis, Rufus (1967). "The Federal Principle Reconsidered," in Aaron Wildavsky (ed.), American Federalism in Perspective Boston: Little Brown.

De Mestral, Armand. (2005). "The Provinces and International Relations in Canada." in J.-F. Gaudreau-DesBiens and F. Gélinas (eds.), The States and Moods of Federalism: Governance, Identity and Methodology. Cowansville: Éditions Yvon Blais, p. 319-322.

De Mestral, Armand, and Evan Fox-Decent (2008). "Rethinking the Relationship Between International and Domestic Law," McGill Law Journal, vol. 53, p. 573.

Dufault, Evelyne. (2006). Demi-tour: une approche sociologique des renversements de politique étrangère. Le cas de la politique étrangère environnementale canadienne, Thesis (Ph.D), Montréal Sciences politiques: Université du Québec à Montréal, 331 p.

Fafard, Patrick. and Leblond, Patrick. (2013), « Closing the deal : What role for the provinces in the final stages of the CETA negociations ? "International Journal, PP.553-559.

Gauvin, Jean-Philippe (2012). "Les relations intergouvernementales au Canada: gage de succès ou d'échec?," Options politiques, p. 38-41.

Government of Canada (1968), Federalism and International Relations, Ministry of Foreign Affairs, Ottawa.

Government of Canada (1968), Federalism and International Conference on Education, Ministry of Foreign Affairs, Ottawa. 
Gouvernement du Québec. «Le Québec et les changements climatiques: Un défi pour l'avenir. Plan d'action 2006-2012.» Ministère du Développement durable, de l'Environnement et des Parcs. 2008.

Goldenberg, Eddie (2006). The Way it Works: Inside Canada, Toronto: McClelland \& Stewart.

Haas, Peter M., Robert O. Keohane and Marc A. Levy (1993). Institutions for the Earth. Sources of Effective International Environmental Protection, Cambridge: The MIT Press.

Harrington, Joanna (2005). "Redressing the Democratic Deficit in Treaty Law Making: (Re-) Establishing a Role for Parliament," McGill Law Journal, vol. 50, p. 465-509.

Harrison, Kathryn (1996). Passing the Buck. Federalism and Canadian Environmental Policy, Vancouver: UBC Press.

Harrison, Kathryn (2007). "The Road Not Taken: Climate Change Policy in Canada and the United States," Global Environmental Politics, vol. 7, no 4, p. 92-117.

Hocking, Brian (1993). Localizing Foreign Policy. Non-central Governments and Multilayered Diplomacy. New York: St-Martin's Press.

Hooghe, Liesbet, and Gary Marks (2003). "Unravelling the Central State, but How? Types of Multi-Level Governance," American Political Science Review, vol. 97, no 2, p. 233-243.

Jeffery, Charlie (2000). "Sub-National Mobilization and European Integration: Does it Make Any Difference?," Journal of Common Market Studies, vol. 38, no 1.

Kukucha, Christopher (2013). « Canadian sub-federal governments and CETA: Overarching themes and future trends » International Journal, pp.528-535.

Kukucha, Christopher (2008). The Provinces and Canadian Foreign Trade Policy, Vancouver, UBC Press.

Kukucha, Christopher (2009). «Dismembering Canada ? Stephen Harper and the Foreign Relations of Canadian Provinces », Review of Constitutional Studies, vol.14, Issue 1.

Kukucha, Christopher (2010) « Provincial Pitfalls: Canadian Provinces and the Canada-EU Trade Negotiations », Association Canadienne De Science Politique, 82e Congrès Annuel Université Concordia, 2010.

Lidskog, Rolf, and Ingemar Elander (2010). "Addressing Climate Change Democratically. MultiLevel Governance, Transnational Networks and Governmental Structures," Sustainable Development, vol. 18, no 1, p. 32-41.

Macdonald, Douglas (2009). "The Failure of Canadian Climate Change Policy: Veto Power, Absent Leadership, and Institutional Weakness," in Debora L. VanNijnatten and Robert Boardman (eds.), Canadian Environmental Policy and Politics. Propects for Leadership and Innovation Toronto: Oxford University Press, p. 152-166. 
Macdonald, Douglas, and Heather A. Smith (1999). "Promises Made, Promises Broken:

Questioning Canada's Commitments to Climate Change," International Journal, vol. 55, no 1 , p. 107-124.

Macdonald, Douglas, and Debora L. VanNijnatten (2005). "Sustainable Development and Kyoto Implementation in Canada: The Road Not Taken," Policy Options, p.13-29.

Macdonald, Douglas, and Debora L. VanNijnatten (2010). "La politique canadienne en matière de changements climatiques et l'influence nord-américaine," Gouvernance, vol. 7, no 1.

May, Elizabeth (2007). "Brian Mulroney and the Environment," in R. B. Blake (ed.), Transforming the Nation: Canada and Brian Mulroney Montreal: McGill-Queen's University Press, p. 381-392.

Martin, Lisa L. (2000), Democratic Commitments: Legislatures and International Cooperation, Princeton (N. J.), Princeton University Press, 2000.

Meekison, J. Peter (2004). Relations intergouvernementales dans les pays fédérés: Une série d'essais sur la pratique de la gouvernance fédérale. Ottawa: Forum des Fédérations.

Michelmann, Hans ed. (2009), Foreign Relations in Federal Countries (Montreal : McGill University Press).

Milner Helen V. and B. Peter Rosendorff (1997), "Democratic Politics and International Trade Negotiations. Elections and Divided Governments as Constraints on Trade Liberalization", Journal of Conflict Resolution, 41, p. 117.

NEG-ECP. (2001). Climate Change Action Plan, Conference of New England Governors and Eastern Canada Premiers, $21 \mathrm{p}$.

Okereke, Chukwumerije, Harriet Bulkeley and Heike Schroeder (2009). "Conceptualizing Climate Governance Beyond the International Regime," Global Environmental Politics, vol. 9, no 1, p. 58-78.

Ott, Hermann E., Wolfgang Sterk and Rie Watanabe (2008). "The Bali Roadmap: New Horizons for Global Climate Policy,” Climate Policy, vol. 81, no1, p. 91-95.

Paquin, Stéphane (2006). Histoire des relations internationales du Québec. Montréal: VLB éditeur: $357 \mathrm{p}$.

Paquin, Stéphane (2004). Paradiplomatie et relations internationales: théorie des stratégies internationales des régions face à la mondialisation. Brussels: Presses interuniversitaires européennes-Peter-Lang.

Paquin, Stéphane (2005). "Quelle place pour les provinces canadiennes dans les organisations et les négociations internationales du Canada à la lumière des pratiques au sein d'autres fédérations?," Administration publique du Canada / Canadian Public Administration, volume 48, No. 4, pp. 477-505. 
Paquin, Stéphane (2010). « Federalism and Compliance with International Agreements: Belgium and Canada Compared », The Hague Journal of Diplomacy, 5, 2010, p.173-197

Paquin, Stéphane (2013). «Federalism and the Governance of international trade negotiations in Canada: comparing CUSFTA with CETA ». International Journal, pp.545-552.

Patry, André (1980). Le Québec dans le monde, Montréal: Leméac.

Piattoni, Simona (2010). The Theory of Multi-level Governance. Conceptual, Empirical and Normative Challenges, New York: Oxford University Press.

Putnam, Robert (1988) « Diplomacy and Domestic Politics : The Logic of Two-Level Games », International Organization, 42 (3), 1988, p. 427-460.

Québec. (1995). Éléments de planification québécoise du développement durable, Québec, Ministère de l'Environnement et de la Faune.

Québec. (2001). L'Assemblée nationale du Québec appuie à l'unanimité le protocole de Kyoto: Communiqué de presse c010410a, Québec, Assemblée nationale du Québec.

Québec. (2006). Journal des débats - Débats de l'Assemblée nationale, Assemblée nationale du Québec, [online], <http://www.assnat.qc.ca/Archives/fra/37legislature2/Debats/journal/ch/061108.htm _Toc150845481>.

Québec. (2007). Gazette officielle du Québec, décret 1074-2007, January 3, 2008, 140th year, no 1, Gouvernement du Québec.

Robitaille, Antoine (2006). "La France défend le Québec à Nairobi. Une sorte de "Vive le Québec vert" vite dénoncé par Ottawa," Le Devoir, 17 November 2006.

Savoie, Donald J. (2004). "Power at the Apex: Executive Dominance," in James Bickerton and Alain G. Gagnon (eds.), Canadian Politics, 4th edition, New York: Broadview Press.

Scharpf, Fritz W. (1988). "The Joint-Decision Trap: Lessons from the German Federalism and European Integration," Public Administration, vol. 66, no 3, p. 239-278.

SCIC. (1997a). News Release - Joint Communiqué First Ministers' Meeting Ottawa - December 12, 1997, Secrétariat des Conférences intergouvernementales canadiennes, [online], $<$ http://www.scics.gc.ca/english/conferences.asp?a=viewdocument\&id=817\%3E.

SCIC. (1997b). Réunion conjointe des sous-ministres de l'environnement et de l'énergie: Communiqué de presse 830-599/00, Regina.

Shaw, Malcolm N. (2008). International Law, 6th edition, Cambridge: Cambridge University Press. 
Simeon, Richard (2004). "Conclusion," in J.P. Meekison (ed.), Relations intergouvernementales dans les pays fédérés: Une série d'essais sur la pratique de la gouvernance fédérale Ottawa: Forum des Fédérations.

Simpson, Jeffrey, Mark Jaccard and Nic Rivers (2008). Hot Air. Meeting Canada's Climate Change Challenge, 2nd edition, Toronto: McClelland \& Stewart.

Skogstad, Grace (2012). "International Trade Policy and Canadian Federalism: A Constructive Tension," in Herman Bakvis \& Grace Skogstad (eds.), Canadian Federalism:

Performance, Effectiveness and Legitimacy, 3rd ed. Toronto: Oxford University Press.

Smith, Heather A. (1998). Canadian Federalism and International Environmental Policy Making: The Case of Climate Change, Working Paper, Institute of Intergovernmental Relations.

Smith, Heather A. (2008). "Political Parties and Canadian Climate Change Policy," International Journal, vol. 64 , no 1, p. 47-66.

Stilborn, Jack. (2003). "Canadian Intergovernmental Relations and the Kyoto Protocol: What Happened, What Didn't," in CPSA 2003 Conference, 24 p.

Stoett, Peter. (2009). "Looking for Leadership: Canada and Climate Change Policy". In Henrik Selin \& Stacy D. VanDeveer (eds.). Changing Climates in North American Politics. Institutions, Policymaking, and Multilevel Governance. Cambridge: The MIT Press.

Twomey, Anne (2009), " Commonwealth of Australia », dans Michelmann, Hans ed. (2009), Foreign Relations in Federal Countries (Montreal : McGill University Press).

UNDP. (2007). Human Development Report 2007/2008., New York: Human Development Report Office, United Nations.

VanDuzer, Anthony J. (2013). «Could an Intergovernemental Agreement Increase the CRedibility of Canadian Treaty Commitments in areas of Provincial Jurisdiction ? ». International Journal, pp. 536-544.

VanNijnatten, Debora L. (2009). "The North American Context: Canadian Environmental Policy and the Continental Push," in Debora L. VanNijnatten and Robert Boardman (eds.), Canadian Environmental Policies and Politics Don Mills: Oxford University Press, p. 92108.

VanNijnatten, Debora L., and Robert Boardman (2009). Canadian Environmental Policy and Politics. Don Mills: Oxford University Press

WCI. (2010). Design for the WCI Regional Program, [online], $<$ http://www.westernclimateinitiative.org/document-archives/funcdownload/282/chk,2d1bfc45071e699f529021448fe8b361/no_html,1/ >.

Wheare, Kenneth C. (1967). Federal Government, Oxford: Oxford University Press. 
Windfield, Mark S., and Douglas Macdonald (2008). "The Harmonization Accord and Climate Change Policy: Two Case Studies in Federal-Provincial Environmental Policy," in Herman Bakvis and Grace Skogstad (eds.), Canadian Federalism: Performance, Effectiveness and Legitimacy, 2nd edition, Toronto: Oxford University Press, p. 266-288. 